\title{
The Application of the Verified Gross Mass of Intermodal Loading Units in the Conditions of the Slovak Republic
}

\author{
Juraj Jagelčák \\ University of Žilina \\ Faculty of Operation and Economics \\ of Transport and Communications \\ Department of Road and Urban transport \\ Slovak Republic \\ e-mail: juraj.jagelcak@fpedas.uniza.sk
}

\author{
Monika Kiktová \\ University of Žilina \\ Faculty of Operation and Economics of \\ Transport and Communications \\ Department of Road and Urban \\ Slovak Republic \\ e-mail: monika.kiktova@fpedas.uniza.sk.
}

\author{
| Mária Stopková \\ Institute of Technology and Business in \\ České Budějovice \\ Faculty of Technology, Department of \\ Transport and Logistics \\ Czech Republic \\ e-mail: stopkova@mail.vstecb.cz
}

Summary

This paper focuses on the methods of obtaining Verified Gross Mass of packed containers or other Intermodal Loading Units in Slovakia taking into consideration requirements of section 4 to 6 , Regulation 2, Part A, chapter VI SOLAS and article 10 of the EU directive 2015/719/EU. The methods which used in Slovakia are described where the comparative analysis of selected weighing methods is performed on selected examples from loading organisations. The paper also recommends the use of certain weighing methods for the selected loading organisations as appropriate procedures to obtain Verified Gross Mass of packed containers or other Intermodal Loading Units.

\author{
DOI 10.17818/NM/2018/4SI.10 \\ UDK 62-758.1 \\ 347.795 \\ Original scientific paper \\ Paper accepted: 28. 8. 2018.
}

\author{
KEY WORDS \\ verified gross mass \\ tare \\ container \\ intermodal loading units \\ weighing method
}

\section{INTRODUCTION}

Verification of the gross mass of packed containers and other intermodal loading units (further as ILU) requires increased attention since the incorrect load distribution of maritime container has direct impact on the handling safety in terminals and on the road, rail and sea transport. Wrong declared container gross mass often means overloading of vehicles, railway wagons, vessels and of handling equipment in terminals [1], [2].

The Maritime Safety Committee (MSC) of International Maritime Organisation approved for adoption at MSC 94 in November 2014 draft amendments to SOLAS chapter VI to require mandatory verification of the gross mass of containers, either by weighing the packed container or by weighing all packages and cargo items and adding the tare mass. The Committee also approved the related draft guidelines regarding the verified gross mass of a container carrying cargo to be issued as an MSC circular [3]. Article 10 of the EU directive 2015/719/EU requires also mass declaration for containers and swap bodies during road transport to know that road vehicles are not overloaded [4-7].

For this reason, Methodological Guideline no. 39/2016 on the verification of the gross mass of packed containers and other intermodal loading units was prepared for Slovak republic where one of the authors of this paper was responsible to prepare this guideline.

\section{APPLICABLE WEIGHING INSTRUMENTS}

For the Verification of the gross mass of packed containers and other intermodal loading units it is necessary to use weighbridge, axle or wheel weighing instruments:

- non-automated weighing instruments of accuracy class III or IIII as per EN 45501,

non-automated weighing instruments to statically determine the mass of the axle or wheel of road vehicles of accuracy class III or IIII as per EN 45501, automated weighting instruments for the weighing of road vehicles in motion and for the measurement of the axle load of the accuracy class $0.2 ; 0.5 ; 1$ for vehicle gross mass and accuracy classes A, B, C for single axle load and group of axles load as per OIML R134-1.

The non-automated weighing instrument is a measuring device used to determine the mass of a body using the gravitational effect of the body, which when weighing requires the operator intervention and may also serve to determine other dimensions, quantities, parameters or characteristics that are derived from weight.

Non-automated weighing instruments must be classes III or IIII.

Automated weighting instruments for the weighing of road vehicles in motion equipped with a load carrier including a platform that determines and indicates the mass of the vehicle or determines and indicates the mass of the vehicle and vehicle axle load or determines and indicates mass of the vehicle, vehicle axle load and vehicle group of axles loads during its passage through load carrier. Weighing instruments for the weighing vehicles in motion shall be at least the accuracy class 1 for the mass of the vehicle and accuracy class $C$ for the single axle load and group of axles load or the higher accuracy class [3], [6-8].

\section{VERIFICATION OF THE GROSS MASS OF PACKED CONTAINER/ILU USING METHOD}

Method 1 (M1) is further divided into three types of weighing. In a method marked as M1A, the container / ILU shall be weighed directly on the weighbridge, where the weighing result is verified gross mass of the packed container / ILU (further as VGM).

In a method referred to as M1B, the container/ILU is weighed on the vehicle/vehicle combination by two measurements on the weigh bridge. Vehicle/vehicle combination is weighed with 
packed container/ILU and without container / ILU.

The M1C method identifies the similar case, but with the use of wheel/axle scale. The VGM is determined as follows [3], [6], [9]:

$$
\begin{gathered}
V G M=m_{c(V / J S+L K)}-m_{c(V / J S)} \\
V G M \leq M G M
\end{gathered}
$$

where:

VGM verified gross mass of packed container/ILU $(\mathrm{kg})$,

$m_{c(V / S+L K)}$ total mass of vehicle/vehicle combination with packed container/ILU $(\mathrm{kg})$ determined by weighing,

$m_{c(v / s)}$ total mass of vehicle/vehicle combination without container/ILU $(\mathrm{kg})$ determined by weighing,

MGM maximum total mass of the container $(\mathrm{kg})$; for the container is this mass indicated on the Safety Approval Plate under the International Convention on Safe Containers (CSC) and usually also on containers.

\section{VERIFICATION OF THE GROSS MASS OF PACKED CONTAINER/ILU USING METHOD 2}

Method 2 can be used for obtaining VGM of packed container/ ILU by weighing all packages and cargo units including the mass of pallets, filling and other loading and securing material to be loaded into the container/ILU and adding the mass of empty container/ILU (tare) to the sum of the individual masses. This method is divided into two cases.

The first one is weighing of the entire cargo in the container/ ILU on the vehicle/vehicle combination and the addition of the mass of empty container/ILU to the gross mass of the cargo. If weighbridge is used, this method is referred to -as M2A. For the same verification of the gross mass of packed container /ILU but using the wheel/axle scale, this method is referred as M2B.

The last case of verifying the gross mass of the packed container/ILU using Method 2 is weighing all packages and cargo units including the weight of pallets, filling and other loading and fixation material to be loaded into the container/ ILU and adding the mass of empty container/ILU (tare) to the sum of the individual masses. Non-automated weighing instruments as per EN 45501 of at least the accuracy class III (for example, platform scale, pallet scale, weighing forks, pallet truck with scale, crane scale). This method is referred as M2E [6], [10].

$$
V G M=\sum_{i=1}^{n} m_{i(B ; J N ; P)}+\sum_{j=1}^{m} m_{j(V M ; L M ; U M)}+m_{K}
$$$$
V G M \leq M G M
$$

VGM verified gross mass of container/ILU $(\mathrm{kg})$,

$m_{i(B ; N ; P)}$ total mass of the individual packages or cargo units or pallets $(\mathrm{kg})$, determined by weighing,

$m_{j(V M ; U M)}$ total mass of the filling and other loading and securing material $(\mathrm{kg})$, determined by weighing,

$m_{k} \quad$ mass of empty container/ILU (tare) $(\mathrm{kg})$; this mass of container is marked on the container,

MGM maximum total gross mass of the container $(\mathrm{kg})$; for the container this mass is indicated on the Safety Approval Plate under the International Convention on Safe Containers (CSC) and usually also on container itself.

The sender who loaded the container / ILU to the vehicle/ vehicle combination is obliged to request and the carrier is obliged to provide information from the vehicle registration certificate about the operating mass of the vehicle/vehicle combination not later than before the container /ILU is packed.

The sender who loaded the container / ILU can't exceed the maximum allowed gross mass of the vehicle/vehicle combination.
When granular or powder solid bulk substrates are transported, forward or rearward movement of the substrates may occur during transport due to braking. It may result in unintentional and considerable overloading of axles, although the total vehicle/combination gross mass meets the legislative requirements. This may be also related to the safety risks [4].

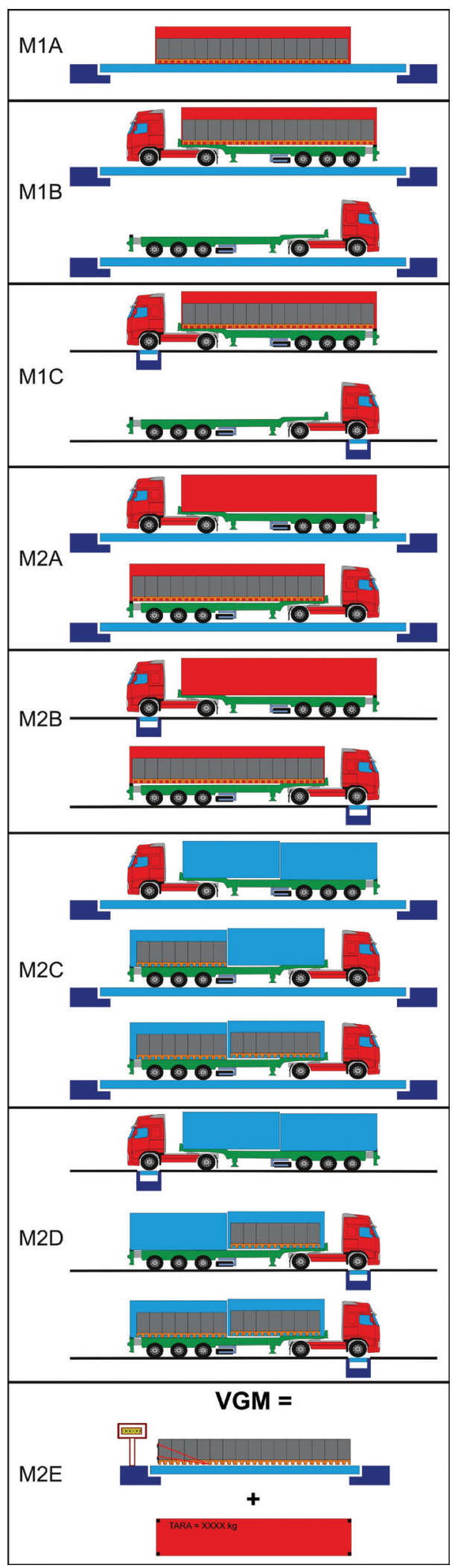

Source: authors

Figure 1 Different methods to obtain VGM in Slovakia 


\section{COMPARISON OF ALLOWED TOLLERANCES OF VGM OF PACKED CONTAINER/ILU}

Gross mass of packed container/ILU shall be identified as accurately as possible. In case of discrepancies related to the use of different weighing methods maximum allowed tolerance in Slovakia is +/- $600 \mathrm{~kg}$ for VGM up to $20000 \mathrm{~kg}$ and +/- 3\% for VGM above $20000 \mathrm{~kg}$ [6], [8], [10], [11].

It is always necessary to take into consideration deviation of container/ILU tare mass when using Method 2. Figure 3 shows tare deviation of 30 different types of containers identified by weighing. Majority of weighed containers were with the tare higher than declared.

\section{EXAMPLE Of DETERMINATION OF VGM TOLERANCE}

The filler filled the tank container 22K2 (tare marked on container $3650 \mathrm{~kg}$ ) loaded on the semi-trailer by carrying out the weighing of vehicle combination with the empty container and with the packed container with a non-automated weighing instrument of class III to $60,000 \mathrm{~kg}$ with scale interval $\mathrm{d}=20 \mathrm{~kg}$. The VGM of container is $25530 \mathrm{~kg}$ and was determined using the M2A method.

Two measurements were carried out on non-automated weighing instruments of class III in range $10000 \mathrm{~kg}<\mathrm{m} \leq 40000$ $\mathrm{kg}$ where the maximum permissible error (MPE) in service is $2 \mathrm{~d}$

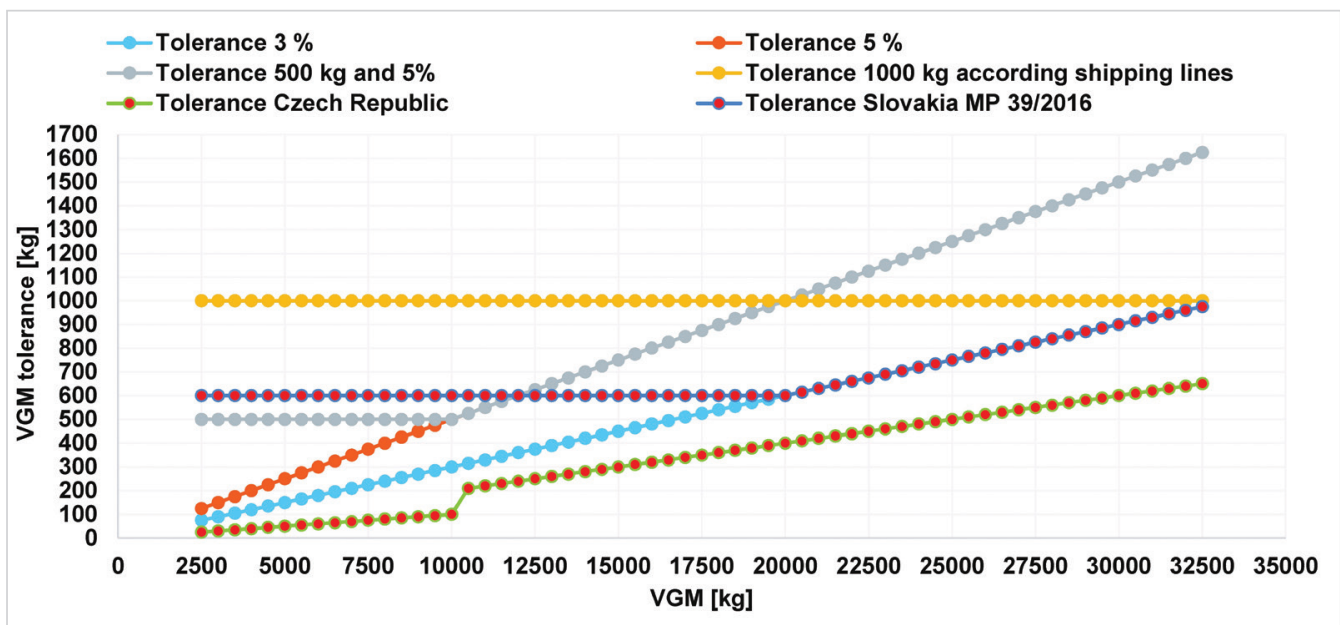

Source: authors

Figure 2 Comparison of selected tolerances used for VGM

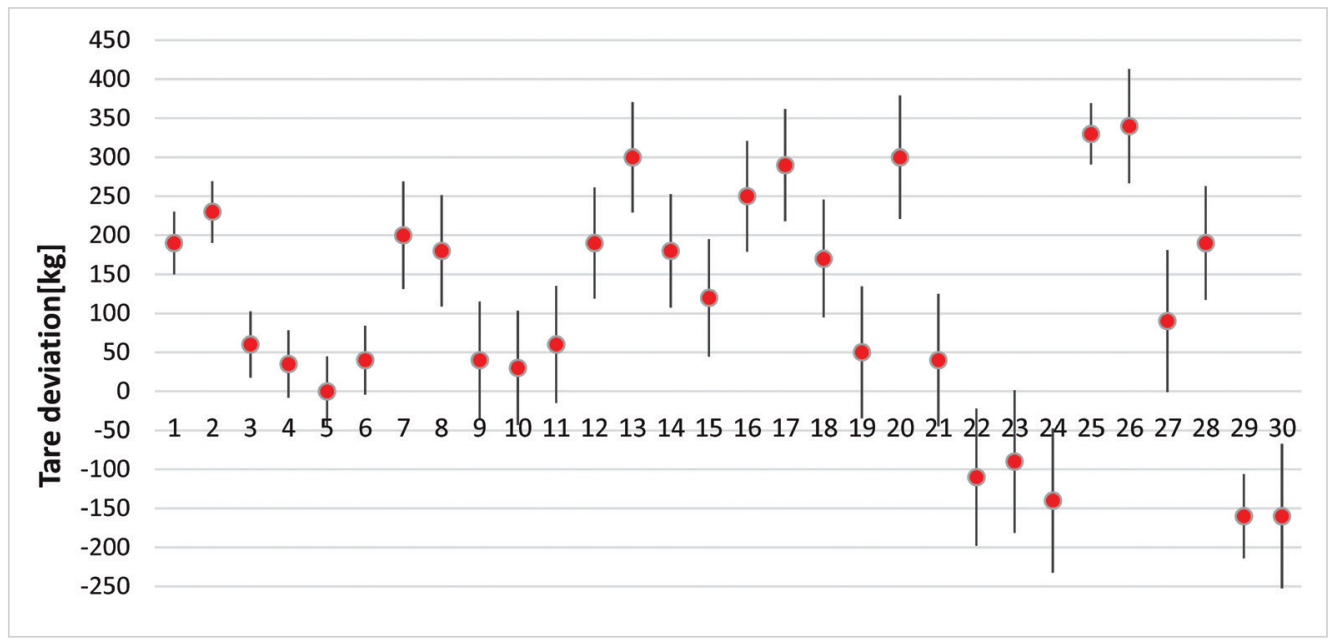

Key: Indication of different containers identified by their size and type code as per ISO 6346, month and year of manufacture and their tare ( $T$ )

$1-(22 \mathrm{G} 1 ; 5 / 2014 ; T=2200 \mathrm{~kg})|2-(22 \mathrm{G} 1 ; 5 / 2014 ; T=2200 \mathrm{~kg})| 3-(22 \mathrm{G} 1 ; 5 / 2012 ; T=2180 \mathrm{~kg})|4-(22 \mathrm{G} 1 ; 10 / 2013 ; T=2185 \mathrm{~kg})| 5-(22 \mathrm{G} 1$ $; 6 / 2007 ; T=2230 \mathrm{~kg})|6-(22 \mathrm{G} 1 ; 2 / 2008 ; T=2230 \mathrm{~kg})| 7-(42 \mathrm{G} 1 ; 4 / 2015 ; T=3640 \mathrm{~kg})|8-(42 \mathrm{G} 1 ; 8 / 2015 ; T=3750 \mathrm{~kg})| 9-(42 \mathrm{G} 1 ; 2 / 2000 ;$ $T=3780 \mathrm{~kg})|10-(42 \mathrm{G} 1 ; 4 / 2004 ; T=3680 \mathrm{~kg})| 11-(42 \mathrm{G} 1 ; 10 / 2002 ; T=3800 \mathrm{~kg})|12-(42 \mathrm{G} 1 ; 11 / 1995 ; T=3740 \mathrm{~kg})| 13-(45 \mathrm{G} 1 ; 7 / 2014 ; T=$ $3830 \mathrm{~kg})|14-(45 \mathrm{G} 1 ; 10 / 2014 ; T=3820 \mathrm{~kg})| 15-(45 \mathrm{G} 1 ; 12 / 2012 ; T=3880 \mathrm{~kg})|16-(45 \mathrm{G} 1 ; 8 / 2011 ; T=3790 \mathrm{~kg})| 17-(45 \mathrm{G} 1 ; 2 / 2004 ; T=3880$ kg) | 18 - (45G1; $7 / 1999 ; T=3940 \mathrm{~kg}) \mid 19-($ LEGB ; 12/2014; T= 4280 kg) | $20-($ LEG1; $11 / 2006 ; T=4260 \mathrm{~kg}) \mid 21-($ LEG1; $1 / 2015 ; T=4280 \mathrm{~kg}) \mid$ $22-(L E G 1 ; 11 / 2006 ; T=4280 \mathrm{~kg})|23-(L E G 1 ; 5 / 2014 ; T=4480 \mathrm{~kg})| 24-(L E G 1 ; 3 / 2013 ; T=4480 \mathrm{~kg})|25-(22 U 1 ; 11 / 2015 ; T=2300 \mathrm{~kg})| 26-$ $(42 U 1 ; 12 / 1995 ; T=3990 \mathrm{~kg})|27-(45 R 1 ; 6 / 2011 ; T=4630 \mathrm{~kg})| 28-(22 \mathrm{~K} 2 ; 9 / 2015 ; T=3830 \mathrm{~kg})|29-(3 D B J ; 9 / 1996 ; T=2540 \mathrm{~kg})| 30-(L E G 1$ ; $3 / 2013 ; T=4480 \mathrm{~kg})$

Source: authors

Figure 3 Deviation between declared tare and tare obtained by weighing on road vehicle in motion from two weighing on axle scale (M1C) of containers of different types and manufacturing date (weighed in 2016). 
(40 kg) valid for one weighing. The cargo gross mass $21880 \mathrm{~kg}$ is determined within an error of $+/-80 \mathrm{~kg}$.

After arrival to the intermodal terminal VGM was determined using the M1C method, with two measurements with automated-weighing instrument for the weighing of road vehicles in motion with accuracy class 1 (MPE in service +/- 1\%). VGM using the M1C was determined as follows:

$V G M_{M 1 C}=m_{c(V / J S+L K)}-m_{c(V / J S)}=36240-10880=25360 \mathrm{~kg} \pm 460 \mathrm{~kg}$

The difference in VGM determination is as follows:

$$
\begin{gathered}
|\Delta V G M| \leq 3 \% \\
\left|1-\frac{V G M_{M 2 A}}{V G M_{M 1 C}}\right| \cdot 100 \leq 3 \% \\
\left|1-\frac{25530}{25360}\right| \cdot 100 \leq 3 \% \\
0.67 \% \leq 3 \%
\end{gathered}
$$

The difference between the VGM determined by the sender who loaded the tank container using M2A and the VGM determined in intermodal terminal using $M 1 C$ is less than allowed tolerance of $3 \%$. The container tare can be established using the results of $\mathrm{M} 2 \mathrm{~A}$ and $\mathrm{M} 1 \mathrm{C}$ as follows:

$T A R E=V G M_{M 1 C}-\left(m_{c(V / J S+L K)}-m_{c(V / / J+K)}\right)=25360-(36400-14520)=3480 \mathrm{~kg} \pm 540 \mathrm{~kg}$

The error of determination of tare using M2A and M1C is too high and therefore the difference $170 \mathrm{~kg}$ between the tare declared $3650 \mathrm{~kg}$ and determined by weighing $3480+/-540$ $\mathrm{kg}$ is within this error. To determine the container tare with the most possible accuracy M1A shall be used where using regular weighbridge within the range $400 \mathrm{~kg}<\mathrm{m} \leq 10000 \mathrm{~kg}$ where the maximum permissible error (MPE) in service is $1 \mathrm{~d}(20 \mathrm{~kg})$.

\section{EXAMPLE OF VGM DETERMINATION IN THE CONTEXT OF ALLOWED TOLERANCES - COMPARISON OF M2E AND M2A METHODS}

Big-bags are filled with bulk material by the sender. One of the reasons is that when solid bulk substrates are transported, their distribution in a vehicle cargo space may change due to inertial forces related to a vehicle movement. [4] For better safety this bulk cargo is filled into big-bags. The sender loads the containers with big-bags packed on wooden pallets.
Big-bags are loaded with bulk material on the nonautomated weighing instrument (weighing range up to 1500 $\mathrm{kg}$, accuracy class III, $\mathrm{d}=0.5 \mathrm{~kg}$ ) with a tolerance of $+/-2 \mathrm{~kg}$, so the mass of big bags after filling is known. The mass is neither assigned to a particular big-bag, nor is it known on which wooden palette which big-bag is loaded. The mass of the wooden pallets is not determined. No other filling, loading and securing material is used where container is packed.

The sender can use the M2A method to determine gross mass of vehicle combination with empty container and packed container by non-automated weighbridge (weighing range $400 \mathrm{~kg}<\mathrm{m} \leq 60000 \mathrm{~kg}$, accuracy class III, scale interval $\mathrm{d}=20 \mathrm{~kg}$ ).

However, the sender considers whether the M2E method can be used to determine the representative mass of the big-bag on the pallet. The VGM could be determined as the number of big-bags multiplied by that representative mass plus container tare.

For this verification, 124 loadings of vehicle combinations were carried out and the gross mass of the cargo was determined with M2A for each loading. 19-25 big-bags were loaded in the container. The average mass of the big-bag on the pallet was determined as cargo gross mass divided by number of loaded big-bags rounded to the entire kilogram. This mass is within the range 1016-1024 kg with an average value / median of $1020 \mathrm{~kg}$, which was determined to be the representative mass for VGM determination, $96.77 \%$ of analysed loadings is within the range of $1020+/-3 \mathrm{~kg}$ [6], [11-13].

Subsequently, the cargo gross mass was estimated by using big-bag representative mass of $1020 \mathrm{~kg}$ multiplied by the total number of loaded big-bags. This value was deducted from the cargo gross mass determined by $\mathrm{M} 2 \mathrm{~A}$ and the deviation of the gross mass was determined taking into consideration weighbridge errors.

The figure 5 shows absolute deviation between cargo gross mass estimated using M2E and weighed using M2A.

The maximum deviation of cargo gross mass between $\mathrm{M} 2 \mathrm{E}$ and M2A method is $+/-200 \mathrm{~kg}$, which represents a deviation of $+/-0.816 \%$ for 24 big-bags in a container with an estimated

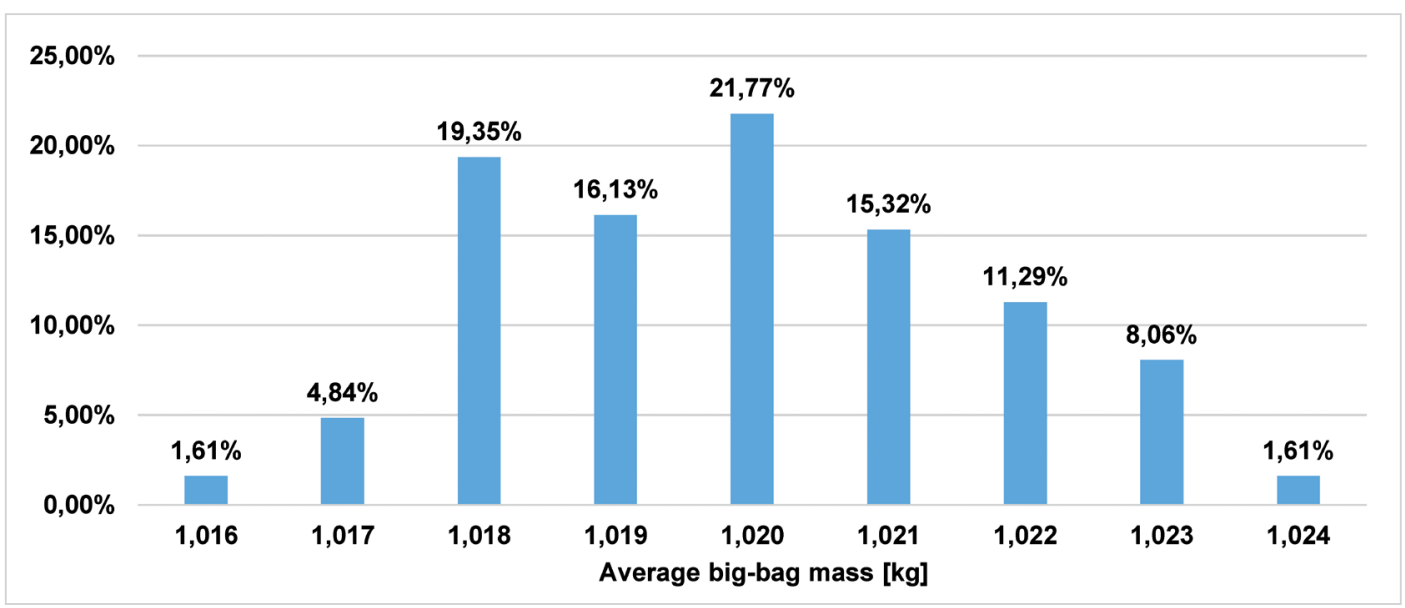

Source: authors

Figure 4 Average big-bag gross mass evaluated from 124 loadings of vehicle combinations using M2A (percentage share from all loadings) 


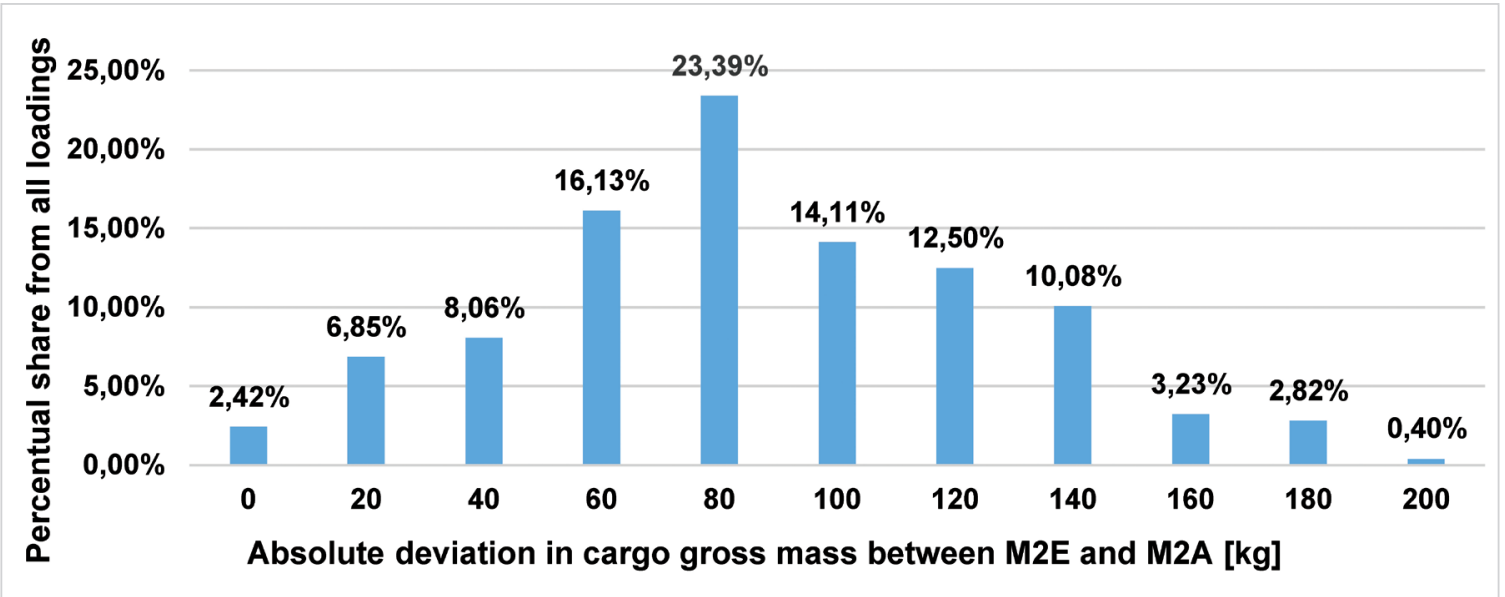

Source: authors

Figure 5 Absolute deviation between cargo gross mass estimated using M2E and weighed using M2A (weighbridge maximum permissible error in service considered)

mass of $24480 \mathrm{~kg}$. If we consider the tare error of $+/-400 \mathrm{~kg}$, then the VGM using M2E is determined within the error of $+/$ $600 \mathrm{~kg}$. This represents a deviation of $+/-2.07-2.09 \%$ for 24 big-bags with estimated mass of $24480 \mathrm{~kg}$, with container tare of $4200-4500 \mathrm{~kg}$. This value is less than tolerance of $+/-3 \%$ and less than $+/-1000 \mathrm{~kg}$ defined by shipping lines. Therefore the sender can determine VGM using the M2E method instead of M2A [14].

\section{COMPARISON OF GROSS MASS OF THE CARGO ACCORDING TO THE M2A AND M2E METHODS}

The sender packs 40 'containers $(42 \mathrm{G} 1,45 \mathrm{G} 1)$ with palletised products that are weighed on non-automated pallet weights of accuracy class III. If wetter wood pallets are used, they dry out during storage, which may cause a mass difference of 3-5 $\mathrm{kg}$ per pallet unit. The gaps between the pallets in container are filled by dunnage bags with gross mass up to $10 \mathrm{~kg}$. Each pallet unit has the gross mass labelled, so the VGM can be determined according to the M2E method.

However, the sender also uses the weighing of vehicle combinations with containers on two weighbridges at the factory entrance, which can also be used to determine the VGM by M2A method. Weighbridges are non-automated weighing instruments of accuracy class III with a scale interval $\mathrm{d}=10 \mathrm{~kg}$ up to $30,000 \mathrm{~kg}$ and $\mathrm{d}=20 \mathrm{~kg}$ up to $60,000 \mathrm{~kg}$. Total number of analysed container is 885 [15-15].

Deviation of the cargo gross mass between M2E and M2A is +/- $280 \mathrm{~kg}$ for $99.44 \%$ of the analysed loadings, but a deviation of $-700 \mathrm{~kg}$ was also observed. If we consider error in container tare of $+/-400 \mathrm{~kg}$ then VGM is determined with error from $+/-680 \mathrm{~kg}$ to $+/-1100 \mathrm{~kg}$.

Table 1 shows possible discrepancy of declared VGM using M2E method.

The results from the analysis show that the M2E method is not suitable for this sender and M2A method shall be used.

Source: authors

Figure 6 Absolute deviation in cargo gross mass using M2E and M2A (weighbridge maximum permissible error in service consid- 
Table 1 Possible discrepancy of VGM for different cargo gross mass, container tare and VGM error using M2E

\begin{tabular}{|c|c|c|c|c|}
\hline \multirow[b]{2}{*}{$\begin{array}{l}\text { Cargo gross mass in con- } \\
\text { tainer }\end{array}$} & \multicolumn{2}{|c|}{ VGM error +/- $680 \mathrm{~kg}$} & \multicolumn{2}{|c|}{ VGM error +/- 1100 kg } \\
\hline & $\begin{array}{l}\text { Container TARE } \\
3500 \mathrm{~kg}\end{array}$ & $\begin{array}{l}\text { Container TARE } \\
4200 \mathrm{~kg}\end{array}$ & $\begin{array}{l}\text { Container TARE } \\
3500 \mathrm{~kg}\end{array}$ & $\begin{array}{c}\text { Container TARE } \\
4200 \mathrm{~kg}\end{array}$ \\
\hline 14500 & $3.78 \%$ & $3.64 \%$ & $6.11 \%$ & $5.88 \%$ \\
\hline 15500 & $4.39 \%$ & $4.39 \%$ & $5.79 \%$ & $5.58 \%$ \\
\hline 16500 & $4.12 \%$ & $4.12 \%$ & $5.50 \%$ & $5.31 \%$ \\
\hline 17500 & $3.89 \%$ & $3.89 \%$ & $5.24 \%$ & $5.07 \%$ \\
\hline 18500 & $3.68 \%$ & $3.68 \%$ & $5.00 \%$ & $4.85 \%$ \\
\hline 19500 & $3.49 \%$ & $3.49 \%$ & $4.78 \%$ & $4.64 \%$ \\
\hline 20500 & $3.32 \%$ & $3.32 \%$ & $4.58 \%$ & $4.45 \%$ \\
\hline 21500 & $3.16 \%$ & $3.16 \%$ & $4.40 \%$ & $4.28 \%$ \\
\hline 22500 & $3.02 \%$ & $3.02 \%$ & $4.23 \%$ & $4.12 \%$ \\
\hline 23500 & $2.89 \%$ & $2.89 \%$ & $4.07 \%$ & $3.97 \%$ \\
\hline 24500 & $2.78 \%$ & $2.78 \%$ & $3.93 \%$ & $3.83 \%$ \\
\hline 25500 & $2.67 \%$ & $2.67 \%$ & $3.79 \%$ & $3.70 \%$ \\
\hline 26500 & $2.57 \%$ & $2.57 \%$ & $3.67 \%$ & $3.58 \%$ \\
\hline 27500 & $2.47 \%$ & $2.47 \%$ & $3.55 \%$ & $3.47 \%$ \\
\hline
\end{tabular}

Source: authors

\section{CONCLUSION}

Basically, there are two Methods to determine VGM according to the SOLAS requirements but several variants of this method can be used. Only variants described in this paper were used in Slovakia because of their practical usability in companies in Slovakia. Determination of VGM by RMG's, RTG's, reach stackers, weighing on railway wagons was not considered as well as determination by just one weighing on road vehicles. Each one of the methods gives different results. Therefore, this shall be taken into consideration where VGM checks are performed. Method 2 is less accurate than Method 1 because there is uncertainty in correct value of container tare. Therefore, it is recommended to include the statement in VGM declaration that the tare mass of the container/ILU has been provided by the shipping line/ILU operator and shipper have no possibility to verify the accuracy of the mass of the empty container/ILU and refuse liability for its accuracy. The method M1E with a lot of different cargo units is a less accurate method to determine VGM and it is recommended to evaluate the error of this method in each company and consider also the error in container tare.

\section{REFERENCES}

[1] Jagelčák, J., Kubasáková, I. Load distribution in general purpose maritime container and the analysis of load distribution on extendable semitrailer container chassis carrying different types of containers. Naše more, 2014, Vol. 61, Issue 5-6, pp. 106-116. ISSN 0469-6255.

[2] Zamecnik, J., Jagelcak, J. Evaluation of wagon impact tests by various measuring equipment and influence of impacts on cargo stability. Communications: scientific letters of the University of Žilina. 2015, Vol. 17, No. 4, s. 21-27, ISSN 1335-4205.

[3] Safety of container ships - weight verification amendments approved. International Maritime Organization, 2014. Available on: http://www.imo. org/MediaCentre/PressBriefings/Pages/16-msc-preview.aspx\#.U8dtgvl_vvQ.

[4] Vrabel, J., Jagelcak, J., Zamecnik, J., Caban J. Influence of Emergency Braking on Changes of the Axle Load of Vehicles Transporting Solid Bulk Substrates. Procedia Engineering. Transportation Science and Technology: Proceedings of the 10th International Scientific Conference, Transbaltica, 2017, Vol. 187, pp. 89-99.

[5] Jagelčák, J., Kubasáková, I. Logistics system just-in-time and its implementation within the company Communications: scientific letters of the University of Žilina. 2016, Vol. 18, No. 2, pp. 109-112. ISSN 1335-4205.
[6] Skrúcaný, T., Kendra, M., Sarkan, B., Gnap, J. Software Simulation of an Energy Consumption and GHG Production in Transport, Tools of Transport Telematics, 2015, Vol. 531, pp.151-160. https://doi.org/10.1007/978-3-319-24577-5_15

[7] Zamecnik, J., Jagelcak, J., Sokier-Peterssen, S. Comparison of acceleration acting on cargo in front and in rear part of semi-trailer during braking with and without using the systems ABS/EBS, Communications: scientific letters of the University of Žilina. 2016, Vol. 18, No. 2, pp. 76-82. ISSN 1335-4205.

[8] Jaehn, F. Positioning of loading units in a transshipment yard storage area. Or Spectrum, 2013, Vol. 35, Issue 2, pp. 399-416. https://doi.org/10.1007/s00291012-0281-8

[9] Skrúcaný T., Gnap J. Energy Intensity and Greenhouse Gases Production of the Road and Rail Cargo Transport Using a Software to Simulate the Energy Consumption of a Train. Mikulski J. (eds) Telematics - Support for Transport TST, Springer, Berlin, Heidelberg, 2014. Communications in Computer and Information Science, Vol. 471, pp. 262-272. https://doi.org/10.1007/978-3662-45317-9_28

[10] Stopka, O., Chovancová, M., Ližbetin, J., Klapita, V. Proposal for optimization of the inventory level using the appropriate method for its procurement. Naše more, 2016, Vol. 63, No. 3, pp.195-199. ISSN 0469-6255.

[11] Skrúcaný, T. et.al. Measuring of noise emitted by moving vehicles. MATEC web of conferences: dynamics of civil engineering and transport structures and wind engineering - DYN-WIND'2017: Trstená, Slovakia, 2017, Vol. 107, No. 00072, pp.8. ISSN 2261-236X

[12] Kubanova J., Schmidt, C. Multimodal and intermodal transportation systems. Communications: scientific letters of the University of Žilina. 2016, Vol. 18, No. 2 pp. 104-108. ISSN 1335-4205.

[13] Kubáňová, J. Poliaková, B. Truck driver scheduling of the rest period as an essential element of safe transport. In: Transport means 2016: proceedings of the 20th international scientific conference, October 5-7, 2016 Juodkrante, Lithuania. Kaunas: Kaunas University of Technology, 2016, pp. 22-26. ISSN 1822-296X.

[14] Blatnický, M., Barta, D. Testing of lightweight construction materials of the transport means. Logi - Scientific Journal on Transport and Logistics, 2012, Vol. 3, No. 1, pp. 23-35. ISSN 1804-3216.

[15] Skrucany, T., Sarkan, B., Gnap, J. Influence of aerodynamic trailer devices on drag reduction measured in a wind tunnel. Eksploatacja i niezawodnosc Maintenance and reliability, 2016, Vol. 18, Issue 1, pp. 151-154. https://doi org/10.17531/ein.2016.1.20

[16] Tai, S. K. The application of the verified gross mass rules in Hong Kong Emerald group publishing LTD. 2016, Vol. 1, Issue 3, pp 225-230. https://doi org/10.1108/MABR-09-2016-0023

[17] Ramos, A. G., Silva, E., Oliveira, J. F. A new load balance methodology for container loading problem in road transportation. Elsevier Science BV, 2017 Vol. 266, Issue 3, pp. 1140-1152. ISSN 0377-2217.

[18] Costa, M. D., Captivo, M.E. Weight distribution in container loading: a case study. EURO Summer Institute Cutting Packing, 2012, Vol. 23, Issue 1-2, pp. 239-263. ISSN 0969-6016. 